\title{
Paideusis
}

\section{Making a Case for Adult Educational Rights}

\section{Kenneth Wain}

Volume 6, Number 1, 1992

URI: https://id.erudit.org/iderudit/1073344ar

DOI: https://doi.org/10.7202/1073344ar

See table of contents

Publisher(s)

Canadian Philosophy of Education Society

ISSN

0838-4517 (print)

1916-0348 (digital)

Explore this journal

Cite this article

Wain, K. (1992). Making a Case for Adult Educational Rights. Paideusis, 6(1),

27-37. https://doi.org/10.7202/1073344ar

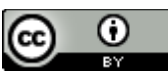

This document is protected by copyright law. Use of the services of Erudit (including reproduction) is subject to its terms and conditions, which can be viewed online.

https://apropos.erudit.org/en/users/policy-on-use/
This article is disseminated and preserved by Érudit.

Érudit is a non-profit inter-university consortium of the Université de Montréal, Université Laval, and the Université du Québec à Montréal. Its mission is to promote and disseminate research.

https://www.erudit.org/en/ 


\title{
Making a Case for Adult Educational Rights
}

\author{
Kenneth Wain, University of Malta
}

\section{Introduction}

Do adults have educational rights, positive moral rights, welfare rights of the kind that imply correlative duties of provision by others? The recognition of autonomy rights-rights of non-interference in the free pursuit of their continuing education by adults-is already firmly embedded, formally recognised and guaranteed in the rationale of liberal democratic societies and needs little if any defence. It is welfare rights that I shall be directly concerned with since welfare rights are virtually unrecognised and problematic. Always within the context of liberal democratic societies, they are rarely, if ever, claimed by adults themselves, notwithstanding the growth of adult education everywhere. The object of this article is to make a case for such rights.

Perhaps many adults identify education with schooling, or with the institutional extensions of schooling, or even with childhood. As Illich would put it, not only education but social reality itself has become schooled. ${ }^{1}$ It may, thus, appear ludicrous to them to claim it as a right for themselves. Besides, the assumption has taken root over time that one's 'chance' to obtain an education is during childhood and that any 'second chance' subsequently offered by society has the nature of a concession to, or an investment in, the individual rather than a right. Other common attitudes which militate in favour of the assumption that welfare rights to education are only for children include the tendency to identify education with preparation for adult life-moral, economic, and social; to view it in terms of the 'girders' that need to be put in for the proper upbringing of children and to connect it with coercive practices; and to think of it as necessarily involving compulsion or, at any rate, an authority relationship between a student and a 'teacher'.

The first point to make concerns this tacit assumption among adults that welfare rights to education do not apply to them. This is conditioned by a perception of education as identical with schooling and, therefore, conceptually linked with childhood, upbringing, coercion, and a teacher's authority. A different perception of education, its meaning and importance-for example, the perception that it needs to be regarded as a lifelong process-could radically change the attitude of many adults towards it. Another is that most writers and theorists on education seem to share the conventional perception for one rarely encounters them arguing for adult education rights. A case in point is a recent book on ethical issues in adult education ${ }^{2}$ where the word 'rights' does not even appear in the index. Among philosophers, much has been written about the right to education for children, ${ }^{3}$ but virtually nothing about adults. ${ }^{4}$

Meanwhile, I shall work within a framework of assumptions that are nearly universally acknowledged and are fundamental to the case I shall make. The first is that moral rights are intelligible notions and important to the realm of moral discourse. The second is that the general class of moral rights includes not only autonomy but also welfare rights. The added caveat here is that the notion of welfare rights is coherent within certain political philosophies but not within others. It is at home within a socio-political ethic of welfare and distribu- 
tive justice, and is utterly out of context within the framework of a minimal, or 'nightwatchman,' state where the rights that are acknowledged as sideconstraints on action are restricted to liberties. ${ }^{5} \mathrm{My}$ final assumption concerns the concept of education itself which I take to be 'contestable,' i.e., open to different, even competing or conflicting, interpretations. All these assumptions appear right, or at least reasonable, to me though they cannot be argued for or defended in this paper.

\section{Can the Case for Children's Rights be Extended to Adults?}

The fact that justified welfare claims against adults are taken to be the basis of corresponding educational rights for children, hinders rather than helps the case for extending such rights to adults. This is because it invites the suspicion that what one is really after in advocating them is a patemalistic excuse for controlling the conduct of adults. This may be one reason for its neglect in the short history of philosophy of education and elsewhere. Philosophy of education, in particular, has been dominated in recent years by a liberal paradigm which, in general, assumes the overarching value of personal autonomy as the ultimate educational aim and which is nearly exclusively occupied with schooling, and these orientations are arguably hostile to the idea of making any such case.

This concern with schooling, in particular, has, more generally, discouraged any philosophical discussion at all of questions relating to adult education, as can be gauged from how few philosophers have written about it, and of the broader aspects of learning that are non-formal and informal which are typical in adult education. If one takes the achievement of autonomy as the focal educational aim and combines it with this identification of education with schooling, one has a ready explanation for the absence of any discussion of adult welfare rights to education. Children are generally admitted to have welfare rights precisely because they are deemed incapable of exercising autonomy. With adults, on the other hand, the very assumption of their practical and moral autonomy, which makes patemalistic attitudes towards them objectionable, disqualifies them from that claim to dependence upon which children's welfare right to education rests. Their autonomy, in this case, works in two ways for adults: it protects them from undue interference with their freedoms, but it also disqualifies them from the right to help.

With children, their lack of capacity for autonomy is used to justify compelling them to go to school, even against their will. The contradiction involved in ascribing a right to somebody and simultaneously declaring it a compulsory obligation is resolved, in the case of children, with the argument that that same incapacity justifies shifting the power to administer their rights from children on to others-their guardians. But this solution is not open in the case of adults, whose autonomy gives them absolute charge of their own welfare. In short, as long as education is thought of as schooling or, with respect to adult education, as the extension of schooling into later life, this underlying contradiction militates against regarding it as a welfare right for adults. 


\section{The Human Rights Argument}

A more promising approach may lie in characterising adult welfare rights to education as human rights. The Universal Declaration of Human Rights roundly declares that "Everyone has a right to education" (Article 261); it does not specify that the right is restricted to children only. One practical problem with the human rights approach, apart from the customary philosophical ones levelled against it, is the variety of different, often dubious, interests that are today defended in its name. Today, as one philosopher has put it, "the rhetoric of rights is out of control" and this is because the proponents of human rights are unclear among themselves about how they are justified, whether they are "inalienable, prescriptible, forfeitable, defeasible, or self-evident." 6 The intelligibility of human rights will not be discussed here. Intelligible or not, they are common currency in contemporary moral debate and appealing to them has a powerful appeal and this popularity is a measure of their success. What is at issue is whether one can take advantage of this universally acknowledged human right to educate children to claim a similar right for adults on the grounds that one does not cease to be human when one is an adult.

There are mundane reasons for saying no. The statement in the Declaration itself which says that everyone has a right to education, leaves it open as to what this might mean in concrete terms. It is, therefore, not difficult to justify any actual educational arrangement already in force against it. The fact that the right to education is recognised as a human right need not, in itself, imply that one has an absolute claim to educational resources for as long as one is alive, like some open-ended cheque that is permanently negotiable. It is sometimes claimed with perfect justification that the prescription contained in the claim that education is a human right is satisfied if everyone, at some time in his/her life, has access to it. A compulsory universal education for children satisfies this condition. Moreover, the bare claim that education is a human right leaves open the equally basic question of whether it is an autonomy or a welfare right. It could be either, though it is commonly supposed to mean only the latter.

Olafson, ${ }^{7}$ who dismisses the human rights justification even in the case of children, has argued instead that the right to education ultimately rests on collective generational duties that adults owe to children. Collective generational duties are duties that are correlative with rights that have their basis not in claims that children may have as human beings, but in obligations that one generation owes to another. All adults, he argues, owe these duties by sheer virtue of their membership in society, since their own prior readiness to accept the benefits of education from others who preceded them makes it illogical for them to shirk the same duty when their turn comes. He also adds two supporting arguments that could be made for children's educational rights without resorting to classifying them as human rights. The first derives from the child's status as a fellow-citizen-to-be who eventually will have the political rights and duties of membership in a democratic society which $\mathrm{s} / \mathrm{he}$ will be expected to perform responsibly:

These rights would be illusory and the duties they entail unfair if the requisite level of education were not assured. It follows that the whole body of citizens who assign these rights and duties to one another have a duty to make such a level of educational attainment possible for all. ${ }^{8}$ 
The other turns on the prima facie inconsistency involved in disclaiming responsibility for the education of others when one is actually benefiting from the education on public offer to them by the very fact that their being educated enriches, or will eventually enrich, the general social climate in which one lives.

These arguments base the duty of educational provision on the moral responsibility of every citizen to bear a part of the cost of public education, rather than on the right of children or anyone else to education. Though not used by Olafson, this argument could be extended to cover responsibility for the education of adults since one benefits from any enrichment of society through the education it offers adults. The question, of course, is whether there is a duty to offer adults education. The first subsidiary argument, on the other hand, assumes a democratic socio-political framework of a given kind.

Olafson himself considers the argument for collective generational duties to be the strongest and most persuasive. But if educational rights are taken to be grounded in such duties, then the extension of such rights to adults seems utterly rule out. ${ }^{9}$ Olafson himself has no doubt that the educational duties of the collective stop with childhood. What he concedes that everyone has a right to is in all cases a basic level of education. He does, however, admit to having difficulties in defining what this 'minimum' is. Any further education would depend on "social need and individual ability rather than any universal human right to indefinitely prolonged public support in the pursuit of one's studies."10

\section{Paterson and the Right to a Liberal Education}

Any sensible debate about educational rights should be clear about what an educational right is, and what precisely is being claimed in its name. Olafson restricts the right to education to a minimum or basic level of education no more, but finds it difficult to define this level. This is understandable because what constitutes a basic level of education is bound to vary with different societies. Dewey, 11 on the other hand, who made a significant distinction between the basic activities of survival (which are common to all species and which broadly involve successful adaptation to an environment) and the particularly human activities of agency and creativity (which may involve the adaptation of the environment itself to their needs and perceptions by human beings) would tend to argue that the education human beings have a right to is something more than the minimal means of survival. In his view, although survival is more urgent, the level at which we are to pitch rights is the fulfilment of one's distinctively human potentiality. Paterson ${ }^{12}$ having in mind the features of a liberal education in his conception of what constitutes the fulfilment of one's distinctively human potentiality, also says yes. Agreeing with Olafson on what they are both discussing as educational rights, namely the right to subsidized 'further studies,' he tries to make a case for extending these rights to adults, but disagrees with the claim that all that society has the duty to provide, in general, are basic or minimal survival rights. The grounds for rights to educational provisions for survival, Paterson claims, exist and are, on the whole, fairly clear, since in a most fundamental sense they belong to "those grave and binding duties societies owe their members to assist them in their efforts of self-preservation."13 But beyond that, he describes a less dramatic, but equally binding, duty societies have to help their members become "fuller and better" people. This duty is 
based ultimately on the general moral principle that we should have an obligation to help our fellow men make the most of themselves and to reach the highest level of humanity and personal worth that they are capable of attaining. ${ }^{14}$

An apparent problem with this argument ${ }^{15}$ is that it is at best defeasible only as a right of imperfect obligation, i.e., a right which, though it corresponds to a reasonable moral claim and is largely recognised as such does not have the import, or 'dramatic' level, to justify its classification as one which imposes collateral binding obligations on others. Thus, the bearers of the right, or society on his/her behalf, would be justified in taking positive action to see that they are fulfilled.

Paterson himself does not argue that the right to become fuller and better people is a right to unlimited learning provision. People cannot, for instance, he says, claim to "have a moral right to be provided with golf coaching or with help in making their own hats or dresses or maintaining their own cars." $16 \mathrm{He}$ also argues that the "intellectual obligation" we have to aid others to be fuller and better people is limited to an adequate provision of resources for the purpose, not to some guaranteed level of attainment. And this makes it different from minimal rights conceived as survival rights, which do, on the contrary, imply a guaranteed level of attainment-the level required to survive. Paterson also claims, again in Kantian fashion, that "Each one of us has a duty to take what steps he can to make himself a better person,"17 but this is by the way; and the notion of a duty owed to oneself is, anyway, a questionable one, as I have argued elsewhere. ${ }^{18}$

Consistent with his liberal position and, again, contrary to Olafson, Paterson also argues that continuing education resources should not be determined by social need or related to social, political, and economic objectives, since this would destroy them as "properly educational courses" and since it would involve "directing educational resources away from those who want or value them to those who do not necessarily either want or value them."19 By deliberately subordinating educational good to the production of varieties of social good, one is creating, says Paterson, a grievous form of social injustice against those who require the former. Nor, in general, he says, should the distribution of educational resources be determined by people's needs, since to determine them in this way is tacitly to ascribe to people a right to some predetermined level of educational attainment. He does concede two exceptional cases where positive discrimination is justified; these favour those who did not receive their full share of educational resources during their childhood and adolescence, and those who live in remote areas or are housebound. But at the same time, he specifically rules out any obligation to make compensatory provisions for cultural disadvantage in adulthood; the time for such is childhood itself, or not at all. Compensatory education is not, he argues, to be thought of as an intrinsic and permanent element in continuing education but as a finite duty to be rapidly discharged and abandoned if the need persists in adulthood.

In sum, Olafson limits society's educational obligations towards its members to a collective generational duty towards the younger generations, arguing that it does not owe adults any educational duties as such and that any additional provision for adult learning should be on the basis of social utility and according to individual merit. Paterson, like Dewey argues for the extension of educa- 
tional rights to adults not only for their survival but also for their self-fulfilment. There are also fundamental differences between the two about the content of education itself and the notion of self-fulfilment which render their respective accounts of such rights radically different. Dewey's conception of education went far beyond studies and schooling. It rebelled against the epistemological rationale of an a priori value-hierarchy of knowledge which allows Paterson to regard golf-coaching, for example, as not educational. And, more fundamentally, Dewey rejected the view that education cannot ever be related to social aims; the distinction between an educational and social good is one that cannot be meaningfully made. Dewey would not have understood 'self-fulfilment' in any but a social sense.

Dewey, in effect, had his own arguments in favour of adult educational rights. He argued that the individual "lives as truly and positively at one stage as at another, with the same intrinsic fullness and the same absolute claims. Thus, he continued, since education means the enterprise of supplying the conditions of growth or adequacy of life," and so must do so "irrespective of age," 20 it must be regarded as a lifelong process. Educational growth, for Dewey, occurs through "that reconstruction or reorganisation of experience which adds to the meaning of experience, and which increases ability to direct the course of subsequent experience," 21 and has no necessary relationship to childhood or youth. Indeed, in his view, infancy, youth, adult life,-all stand on the same educative level in the sense that what is really learned at any and every stage of experience constitutes the value of that experience." 22 Besides, Dewey contended, continuing education is both natural and psychologically indispensable for human well-being. "Every adult," he says, "resents the imputation of having no further possibilities of growth, and, so far as he finds that they are closed to him, he mourns the fact as evidence of loss." 23

Dewey's view of education extended also to the modes of learning education includes. For him, like Rousseau, education is a process open to all sources of leaming, including informal learning from the environment. And this view of education, if it is adopted, obviously renders more complex the question of what the content of educational rights should be and of how the reciprocal entitlements they give rise to can be met. The question of bow cannot obviously be entered into here, but if one includes informal learning from the social environment itself under education, for instance, then one is arguing for the right of adults to an educative environment. It is also evident that such an understanding of education, widely held, would radically change the attitude of adults towards it and encourage them to reassess their own educational needs, rendering adults more disposed to claim resources from society and the state to satisfy these needs.

\section{Social Contract Rights}

Our earlier discussion showed that a successful case for educational welfare rights for adults cannot fall back on arguments that are usually made for the concession of such rights to children. It is clear also that in a liberal-democratic culture it must avoid the suspicion of being covertly patemalistic or being a smokescreen for the added empowerment of coercive social agencies. Proposing the rights as straightforward human rights or as moral rights, as Paterson appears to do, does not do the trick either, though, if there is one area where 
human or moral right claims are strong, it is surely that of personal survival. What seems to be required is some other basis on which to ground moral rights which avoids the problems with human rights and is more persuasive. Dewey's claim that educational rights know no discrimination of age because education is all one with growth, and so, is a lifelong process. It is strong at the level of survival where it is supported by the pragmatic argument that the demands of a fast-changing world make the business of adapting a continuous one, but weaker at that of self-fulfilment where the notion of a distinctively human potentiality is more abstract. In any case, Dewey himself did not argue explicitly for the right to direct social support for either endeavour into adulthood.

Assuming a socio-political context which recognises the principle of distributive justice, such an argument can, however, be made from what Peffer calls social contract rights which are "the rights that a just society, given its concrete conditions of production and so on, deems us to have."24 They are not human rights though, as Peffer points out, they do presuppose a theory of human worth which is the basis of human rights. Their fundamental basis is the principle of distributive justice. Within the class of social contract rights, Peffer distinguishes a well-being subclass which he describes as "a category of rights conceptually connected to our basic needs as human organisms. . .such rights as the rights to those things which we require if we are to survive and to have any sort of life worth living." They, therefore, entail a special urgency compared with those more general social contract rights which "though concerned with benefits of one sort or other, [are] not directly related to our basic needs," 25 and constitute a correlatively stronger entitlement.

This account of welfare rights coincides with our account of the two levels of welfare concerns, for individual survival and self-fulfilment respectively. Rights to well-being, as Peffer describes them, are welfare rights that correspond with the demands of individual survival, while the broader social contract rights can furnish the grounds for, and constitute the limitations of, welfare rights that correspond to the needs of self-fulfilment. Olafson works within a different framework. He bases educational welfare rights on a collective generational duty owed by adults to the young; he acknowledges no similar duties of adults towards other adults. In general, he grounds adult education solely in utility. He also, it will be remembered, expresses difficulty with establishing what this basic education should be, though he does refer to a curriculum of political skills and knowledge that all citizens-to-be of a democracy need to have. Paterson also denies the right to any basic level of educational attainment beyond childhood. The demands of personal survival which would presumably correspond with his cultural needs, with any remedial intervention they may require, should be satisfied at this stage or not at all. The resources for the provision of adult education, for Paterson, must be reserved for the pursuit of liberal education.

But there are problems one would want to raise with this preference for liberal education at the expense of other claims for the provision of adult education. As well, grounding the right to such provision in 'intellectual obligation' leaves it particularly weak as a claim. The framework of social contract rights grounds it instead in justice and prioritises it differently.

Classifying the right to a basic education as an education for survival within the sphere of rights to well-being suggests a different way of determining 
its status. This point will be returned to later. From a more general viewpoint, it follows from this mode of classifying it that the content of this right should be relative to the survival demands on a particular individual in a particular society at a particular time, and this cannot be determined in any way but pragmatically. That it should be made available to children is universally acknowledged both in theory and practice. Olafson and Paterson are in agreement with the conventional view that it should also end with childhood, a view underpinned by the conventional association of education with courses, study, and so on, while Paterson quite simply identifies education with liberal education in general, and obviously shares the prejudices of liberal theorists described at the beginning of the article. What the notion of social contract rights introduces into the picture is the dimension of the just distribution of available resources. It implies, within the logic of a morality of rights, ${ }^{26}$ that there should be no a priori reason for denying the right to further educational resources to adults except their unavailability after the competing demands made on society by other rights that enjoy moral precedence over it have been satisfied. This puts it in competition with the right of children to the available pool of educational resources and with the resources required to satisfy the other rights to well-being that adults also justly claim from their society on the principle of distributive justice-health, nutrition and shelter, for example.

It may well be that adult educational rights score badly on both counts. But this is different from denying their very existence a priori. We do not seem prepared to say that such survival rights as the right to minimal health, and so on, should be suspended with the arrival of adulthood a priori; why then suspend the right to the continuing provision of the resources for minimal education? The argument that health, for example, is necessary for life in the most direct way-literally conditions for physical survival-while education is connected to a kind of survival that is more abstract and less compelling; that the denial of education does not threaten life directly as does the denial of health, and so on, does not really hold. For it is untrue to say that the notion of, say, a minimum of health care is any more straightforward or less abstract than the notion of a minimum of education. ${ }^{27}$ Yet, this does not deter ordinary people who think within the politics of obligation of the welfare state from claiming that a right to a minimum of health care exists. Moreover, they expect their governments, through their national health services, to translate that right into tangible entitlements of different kinds that can be supplied against the demonstration of a legitimate need on the part of the claimant. And even if it did hold, it would merely establish the priority of these rights over that of education, not eliminate the latter.

The limiting factor with health care is taken to be the availability of resources. The availability of resources is, in fact, a basic criterion in the application of the principle of distributive justice which underpins social contract rights. It must be made clear, then, that it is not being argued that the welfare right to continuing adult education provision be regarded as absolute. Distributive justice, as Rawls ${ }^{28}$ pointed out, requires a principle of lexicality in the distribution of its primary goods. It may be that most societies will rank health, housing, and nutrition needs above educational needs on their list. In the poorest societies, even the right to schooling for children may be taken to be justifiably overridden in the interests of the satisfaction of needs that are more 
pressing and dramatic. And it is only in the affluent countries of the developed world that the right to the active aid of society in the pursuit of one's continuing self-fulfilment can be tangibly recognised as a social contract right. But none of this means abandoning one's commitment to the principle that the allocation of resources should be determined according to social contract rights based on distributive justice. These rights must continue to be recognised in principle, wherever distributive justice is recognised in principle. With the understanding that certain welfare rights, among them possibly that of education, whether for the young or for adults, though acknowledged in principle, must rest suspended, where this is the case, because the concrete conditions of a particular society at a particular time do not permit the entitlements to which they give rise to be met.

This matter of distributing available resources would seem to be the real problem for Paterson who denies that survival needs should take priority over those of self-fulfilment (qua liberal education) in their allocation for adult education. But the principle of social contract rights which grants priority to the right to well-being over that of self-fulfilment reverses Paterson's priorities. The task of establishing minimum educational rights on the scale of priorities in the list of rights to well-being and in the general context of social contract rights can only be taken up when the content of educational rights is determined. This, as was intimated earlier, depends on what one includes under education, the sources and resources of learning one takes it to cover. What one includes under education determines what is at stake when one is discussing the distribution and priority of educational resources. It also determines how educational welfare needs should be measured against other needs. Thus, if under educational rights one includes entitlements only to the provisions that are normally associated with and supplied by schools, then the claim to the right to educational resources is exceedingly restricted, will probably rank low in lexicality in the distribution of the social goods of which it is part, and will suffer from exposure to the biases described in the opening paragraph. But if one includes under education everything that Dewey wants to include under it-namely, all the learning, formal, non-formal, and informal, which one requires not only for one's selffulfilment but, more pressingly, for one's very existence as a social being-things are different. It is hard to see, even in the poorest countries, how one can justify not including educational needs at the level of survival, at least, in the very forefront of priorities on a par with health and others, even in the poorest of countries. Self-fulfilment, in its broader sense, liberal or otherwise, may rank further down the scale. 


\section{Notes}

1I. Illich, Deschooling Society (Harmondsworth: Penguin, 1978), 10.

${ }^{2}$ R.G. Brockett, Ethical Issues in Adult Education (New York: Teachers College Press, 1988).

3See, for example, B. Crittenden, "Education as Human Right," Philosophy of Education 1971: Proceedings of the Twenty-seventh Annual Meeting of the Philosophy of Education Society; I. Gregory, "The Right to Education," Proceedings of the Philosophy of Education Society of Great Britain, 25(2), 1973; F. Olafson, "Rights and Duties in Education," in J.F. Doyle (ed.), Educational Judgements (London: Routledge and Kegan Paul, 1973); G. Haydon, "The Road to Education and Compulsory Schooling, Educational Philosophy and Theory, 9(1), 1977; G. Haydon, "The Utility of Wringe's Rights," Journal of the Philosophy of Education, 21(1), 1987; C. Wringe, Children's Rights (London: Routledge Kegan and Paul, 1985); C. Wringe, "The Human Right to Education," Educational Philosophy and Theory, 7(2), 1986.

'One notable exception is R.W.K. Paterson's Values, Education and the Adult (London: Routledge, Kegan and Paul, 1979) which will be discussed later.

${ }^{5}$ R. Nozick, Anarchy, State and Utopia (Oxford: Blackwell, 1984).

${ }^{6}$ L.W. Sumner, "Rights Denaturalized," in G.R. Frey (ed.), Utility and Rights (Oxford: Blackwell, 1985), 37-38.

${ }^{7}$ Olafson, op. cit.

${ }^{8}$ Ibid., 188-189.

9The qualification 'seems' indicates my uncertainty that such duties could not be claimed on behalf of at least one particular class of adults, namely the aged, although the basis for this claim would evidently be a very different one from that made on behalf of children. One could argue, on the basis of Olafson's principle, that those who are now aged have produced at least the basis for society's present wealth and resources and therefore have some right to a return on their input which it is the duty of the present generation, which is in control of their distribution, to provide. This is the sense of Laslett's 1980 "Charter" which became the manifesto of the University of the Third Age movement in Britain. Cf. P. Laslett, "An Educational Charter for the Elderly," New Society, 13 March, 1980.

${ }^{10}$ Olafson, op. cit., 192-193.

11 John Dewey, Democracy and Education (New York: Macmillan, 1916).

12 Paterson, op. cit.

${ }^{13}$ Ibid., 231.

${ }^{14}$ Ibid., 232.

${ }^{15}$ This is similar to the one raised recently by J. Raz in The Morality of Freedom (Oxford: Clarendon Press, 1986) in which he contends that we have a moral duty to aid others in their continuing education derived from a deeper obligation to aid their efforts to achieve autonomy has its basis in Kantian philosophy.

${ }^{16}$ Paterson, op. cit., 233-234.

${ }^{17}$ Ibid., 235.

${ }^{18} \mathrm{~K}$. Wain, "Lifelong Education: A Duty to Oneself?" Journal of the Philosophy of Education, 25(2). 
${ }^{19}$ Paterson, op. cit., 241.

${ }^{20}$ Dewey, op. cit., 51.

${ }^{21}$ Ibid., 76.

22 Ibid.

${ }^{23}$ Ibid.

${ }^{24} \mathrm{R}$. Peffer, "A Defence of Rights to Well-Being," Philosophy and Public Affairs, 8(1), 1978, 65.

25 Ibid., 80.

${ }^{26} \mathrm{R}$. Dworkin, Taking Rights Seriously (London: Duckworth, 1977).

${ }^{27}$ A.E. Buchanan, "The Right to a Decent Minimum of Health Care," Philosophy and Public Affairs, 13(1), 1984, 55-78.

$28 \mathrm{~J}$. Rawls, A Theory of Justice (Cambridge: Harvard University Press, 1971). 